\title{
EFFECTS OF SPATIAL PATTERN AND CULTIVAR ON WEED CONTROL AND GRAIN YIELD IN RICE AT REDUCED RATES OF HERBICIDE
}

\author{
EFEITOS DO PADRÃO ESPACIAL E CULTIVAR ON CONTROLE DE PLANTAS \\ DANINHAS E RENDIMENTO DE GRÃOS DO ARROZ COM TAXAS REDUZIDAS DE \\ HERBICIDA
}

\author{
Hashem AMINPANAH ${ }^{1}$ \\ 1. Assistant Professor, Department of Agronomy and Plant Breeding, Rasht Branch, Islamic Azad University, Rasht, Iran
}

\begin{abstract}
To evaluate the effects of herbicide rate, cultivar, and spatial pattern on rice grain yield and weed suppression, a field experiment was conducted on a lowland rice field at the Rice Research Station of Tonekabon, north of Iran, in 2011. The experimental design was a split plot-factorial where the whole plot portion was a randomized complete block with three replicates. Main plots were pretilachlor rates $\left(0,0.5,1,1.5,2 \mathrm{~L} \mathrm{ha}^{-1}\right.$ of pretilachlor). The subplots were factorial combinations of two crop spatial patterns (uniform and wide-row planting patterns, $20 \times 20$ and $30 \times 13 \mathrm{~cm}$, respectively) and two traditional rice cultivars ('Hashemi' and 'Deylamani'). Regardless of cultivar and spatial pattern, rice grain and biological yields, panicle number per $\mathrm{m}^{2}$, leaf area index, and herbicide efficacy increased, while weed biomass decreased with increasing pretilachlor application rate. Rice grain and biological yields, panicle number per $\mathrm{m}^{2}$, leaf area index, and herbicide efficacy were significantly greater in uniform planting pattern than in wide-row planting pattern when averaged over cultivars and pretilachlor rates. Moreover, uniform planting pattern of rice plants suppressed weeds $39 \%$ better than wide-row planting pattern as averaged across pretilchlor rates and cultivars. 'Deylamani' produced grater grain and biological yields, panicle number per $\mathrm{m}^{2}$, leaf area index than 'Hashemi' as averaged across pretilachlor rates and spatial patterns. This experiment illustrated that uniform spatial pattern increased weed suppression, herbicide efficacy, and grain yield.
\end{abstract}

KEYWORDS: Herbicide. Planting pattern. Rice cultivars. Weed competition.

\section{INTRODUCTION}

Weeds reduce rice grain yield up to the extent of 32\% (SINGH et al., 2007) by competing for space, nutrients, water and light. Moreover, some weeds serve as alternate hosts for pests and diseases. In rice fields of Iran, most important grass weed species are Echinochloa crus-galli (L.) P. Beauv, and Echinochloa oryzicola Vasing, sedges are Cyperus difformis L., Scirpus juncoides Roxb., Scirpus maritimus L., Scirpus mucronatus L., and broad-leaved weed species are Sagittaria trifolia L., and Alisma plantago-aquatica L..

Weed control in rice fields of Iran largely depends on chemical methods, but the development of weed resistance, economic incentives, adverse effects on human and animal health, and unwanted environmental side-effects have served as the impetus for investigating reduced rates of herbicides for weed control (HEAP, 2010; POWLES; YU, 2010). It was hypothesized that combining the weed competitive cultivar with an appropriate spatial pattern could contribute to reduce herbicide rates for weed control in lowland rice systems. Weed competitiveness (WC) is the ability of a crop to suppress and tolerate weeds (JANNINK et al., 2000) which include; 1- weed-suppressive ability (WSA), or the ability of the cultivar to reduce weed growth and subsequent seed production, 2- weed tolerance (WT), or the ability of the cultivar to maintain high grain yield when weeds are present. Crop cultivars can differ in their competitiveness with weeds, and cultivars with strong weed-competitive ability are a low-cost and safe tool for integrated weed management (SPIES et al., 2011; PAYNTER; HILLS, 2009, SHIVRAIN et al. 2009). It has been reported that using rice cultivars with the stronger weed-suppressive ability is an effective method to reduce herbicide rates and may decrease dependence on herbicides in weed control (GIBSON et al. 2001). GEALY et al. (2003) suggested that growing weed-suppressive rice cultivars in combination with reduced herbicide rates could be an effective weed management strategy for rice in the southern United States. Competitive crop cultivars are even more important for weed control in organic agriculture where herbicides are prohibited (MASON et al. 2008). At the same time, agronomic practices such as crop rotation, crop density, and spatial arrangement can be manipulated to reduce weed interference in some crop-weed associations. In north of Iran, rice is transplanted either manually or by rice transplanters. In manual methods, the seedlings are transplanted in straight rows with a 
uniform spacing between plants (at planting distance of $20 \times 20 \mathrm{~cm}$ for traditional cultivars and $25 \times 25$ $\mathrm{cm}$ for improved cultivars), while in machine transplanting; the seedlings are transplanted in straight rows with inter-row spacing of $30 \mathrm{~cm}$ and intra-row spacing from 11 to $19 \mathrm{~cm}$. The use of these machines is increasing because manual transplanting is a labour intensive operation in the cultivation of rice. At the same time, previous studies have shown that crop spatial pattern can affect crop growth, grain yield and herbicide efficacy (OLSEN et al., 2012, OLSEN et al., 2005, WEINER et al., 2001). A recent study, Olsen et al. (2012) observed that increased crop uniformity had a negative effect on weed biomass, and concluded that crop pattern effects on weeds occur only through size-asymmetric competition. Olsen et al. (2005) have shown that a highly uniform pattern of wheat plants suppresses weeds $30 \%$ better than plants distributed in row pattern. Weiner et al. (2001) reported that a highly uniform sowing pattern combined with increased crop density reduced weed biomass in spring wheat by $60 \%$ compared with normal sowing practice. It has been suggested that the most important reason for increasing yield in uniform spatial pattern is decreased intra-specific competition for light, water, and nutrients because of a more equidistant spatial arrangement of plants. Therefore, the objective of this study was to assess whether rice cultivar and crop spatial pattern affect weed suppression, herbicide efficacy and crop yield at reduced rates of herbicide.

MATERIAL AND METHODS

\section{Experimental design, plant culture and management}

A field experiment was conducted on a lowland rice field at the Rice Research Station of Tonekabon ( $\left.36^{\circ} 51^{\prime} \mathrm{N}, 50^{\circ} 46^{\prime} \mathrm{E}\right)$, north of Iran, in 2011. The previous crop was rice. Physical and chemical soil properties, were determined at 0-30 $\mathrm{cm}$ before experiment establishment, were as follows: $19 \%$ sand, $44 \%$ silt, $37 \%$ clay, $6.8 \mathrm{pH}$, $2.2 \%$ organic matter, $0.2 \%$ total nitrogen, $11 \mathrm{mg} \mathrm{kg}^{-}$ ${ }^{1} \mathrm{P}_{2} \mathrm{O}_{5}$, and $112 \mathrm{mg} \mathrm{kg}^{-1} \mathrm{~K}_{2} \mathrm{O}$. Monthly weather data are shown in Table 1. The experimental design was a split plot-factorial where the whole plot portion was a randomized complete block with three replicates. Main plots were pretilachlor rates $(0$, $0.5,1,1.5,2 \mathrm{~L} \mathrm{ha}^{-1}$ of pretilachlor $\left.{ }^{*}\right)(0,25,50,75$, and $100 \%$ of recommended rate, respectively) applied at six days after transplanting, according to the manufacture recommendation. The subplots were factorial combinations of two crop spatial patterns (uniform and wide-row planting patterns, $20 \times 20$ and $30 \times 13 \mathrm{~cm}$, respectively) and two traditional rice cultivars ('Hashemi' and 'Deylamani'). These cultivars are extensively cultivated in north of Iran. Subplot size was 7 rows $\times 4 \mathrm{~m}$, and both cultivars were transplanted on May 19, 2011. Fertilizer was applied as a basal application of $25 \mathrm{~kg} \mathrm{~N}$ as urea, $70 \mathrm{~kg} \mathrm{P}_{2} \mathrm{O}_{5}$ as triple super phosphate and $100 \mathrm{~kg} \mathrm{~K}_{2} \mathrm{O}$ as $\mathrm{KCl}$ per hectare. Additional $\mathrm{N}$ was applied at $25 \mathrm{~kg} \mathrm{ha}^{-1}$ as topdressing at 40 days after transplanting for both cultivars.

*2-Chloro-N-(2,6-diethylphenyl)-N-(2-propoxyethyl) acetamide $(50 \%$ EC)

Table 1. Monthly precipitation and temperature from April to September in 2011 at Rice Research Station of Tonekabon.

\begin{tabular}{lcccc}
\hline \multirow{2}{*}{ Month } & $\begin{array}{l}\text { Precipitation } \\
(\mathbf{m m})\end{array}$ & \multicolumn{3}{c}{ Temperature $\left({ }^{\circ} \mathrm{C}\right)$} \\
\cline { 3 - 5 } & & Maximum & Minimum & Average \\
\hline April & 39.6 & 16.6 & 10.7 & 13.6 \\
May & 10.4 & 21.9 & 16.5 & 19.2 \\
June & 73.9 & 26.8 & 20.8 & 23.8 \\
July & 2.9 & 31.4 & 24.2 & 27.8 \\
August & 131.3 & 28.8 & 23.1 & 25.9 \\
September & 271.1 & 25.4 & 19.7 & 22.5 \\
\hline
\end{tabular}

\section{Plant sampling}

Green leaf area was measured with a leaf area meter (LI-3000A, LI-COR, Lincoln, NE, USA) at 25 and 45 days after transplanting. Leaf area index (LAI) was calculated as the ratio of green leaf area divided by the ground area. Plant height was measured from the soil surface to the tip of the panicle based on 12 individual measurements in each plot just before harvesting. At maturity stage, yield components of rice (panicle number per $\mathrm{m}^{2}$, grain number per panicle, and 1000-grain weight) were measured according to Gomez (1972). Rice 
grain yield, biological yield, and weed biomass were determined from $2.5 \mathrm{~m}^{2}$ per plot. Grain yield was corrected to $140 \mathrm{~g} \mathrm{~kg}^{-1}$ grain moisture content. Biological yield and weed biomass from each plot were dried at $70{ }^{\circ} \mathrm{C}$ for $96 \mathrm{~h}$, and weighted. Harvest index was calculated by dividing the dry weight of the grain by the dry weight of aboveground (biological yield).

\section{Statistical analyses}

The relationship between rice yield and herbicide rate was described using the following quadratic model:

$y=y_{0}+a x+b x^{2}$

Where $\mathrm{y}$ is estimated rice yield as a function of herbicide rate $(\mathrm{x}), \mathrm{y}_{0}$ is rice yield in the absence of herbicide application, and $a \& b$ are calculated regression parameters.

The relationship between weed biomass and herbicide rate was described using the following exponential model:

$\mathrm{y}=\mathrm{a} /\left(1+\exp \left(-\left(\mathrm{x}-\mathrm{x}_{0}\right) / \mathrm{b}\right)\right)$

Where $\mathrm{y}$ is estimated weed biomass as a function of herbicide rate $(\mathrm{x}), \mathrm{a}$ is weed biomass in the absence of herbicide application, $x_{0}$ is the herbicide rate that $50 \%$ inhibition occurred, $\mathrm{b}$ is calculated regression parameter.

The herbicide efficacy was calculated from the following equation (LESNIK, 2003):

$$
H E=\frac{W_{U n}-W_{T}}{W_{U n}}
$$

Where HE is the herbicide efficacy, $\mathrm{W}_{\mathrm{Un}}$ is weeds dry weight in non treated plot with herbicide, $\mathrm{W}_{\mathrm{T}}$ is weeds dry weight in treated plot with herbicide. The relationship between the herbicide efficacy and herbicide rate was described using the following linear model:

$\mathrm{Y}=\mathrm{ax}+\mathrm{b}$

Where $y$ is the herbicide efficacy as a function of herbicide rate $(\mathrm{x}), \mathrm{b}$ is $\mathrm{y}$ intercept and $\mathrm{a}$ is calculated regression parameter.

Analyses of variance were performed using SAS procedures (SAS Institute, 2004). Means were compared using fisher's protected LSD test at
AMINPANAH, $\mathrm{H}$.

$\alpha=0.05$. When interactions between factors were not significant, main effects were presented. Moreover, if the analysis of variance indicated a significant $\mathrm{F}$ value for herbicide rate, a linear, quadratic, or exponential function was fit to the herbicide rate data using regression functions present in the graphics program (SigmaPlot version 10, Systat Software, Inc., Point Richmond, CA). Standard errors were calculated for all means.

\section{RESULTS AND DISCUSSION}

Analysis of variance (Table 2) indicated that the main effect of herbicide rate $(\mathrm{H})$ was significant for plant height $(\mathrm{PH})$, grain yield $(\mathrm{Y})$, relative yield reduction $(\mathrm{RYR})$, panicle number per $\mathrm{m}^{2}(\mathrm{PN})$, grain number per panicle (GN), biological yield (BY), leaf area index at 45 days after transplanting (LAI45), weed biomass (WB), and herbicide efficacy (HE), but was not significant for 1000-grain weight (Thgw), harvest index (HI), and leaf area index at 25 days after transplanting (LAI25). Cultivar (C) had significant effect on plant height $(\mathrm{PH})$, grain yield $(\mathrm{Y})$, relative yield reduction (RYR), biological yield (BY), leaf area index at 25 and 45 days after transplanting (LAI25 and LAI45, respectively), while panicle number per $\mathrm{m}^{2}(\mathrm{PN})$, grain number per panicle (GN), 1000-grain weight (THGW), harvest index (HI), weed biomass (WB), and herbicide efficacy (HE) were not significantly affected by cultivar. Moreover, main effect of spatial pattern (S) was significant for plant height $(\mathrm{PH})$, grain yield $(\mathrm{Y})$, relative yield reduction (RYR), panicle number per $\mathrm{m}^{2}(\mathrm{PN})$, biological yield (BY), leaf area index at 25 and 45 days after transplanting (LAI25 and LAI45, respectively), weed biomass (WB), and herbicide efficacy (HE). In contrast, main effect of spatial pattern (S) was not significant for grain number per panicle (GN), 1000grain weight (Thgw), and harvest index (HI). Effect of $\mathrm{H} \times \mathrm{S}$ interaction was significant only for weed biomass (WB), and herbicide efficacy (HE). Other 2-way interactions were not significant. Also, the 3way interaction was not significant for all traits.

Averaged across cultivar and spatial pattern, plant height of rice was significantly increased from $113 \mathrm{~cm}$ to $130 \mathrm{~cm}(15 \%)$ as herbicide application rate increased from 0 to $2 \mathrm{~L} \mathrm{ha}^{-1}$ (Table 2). This is probably due to better weed suppression at higher application rate of pretilachlor. 
Table 2. Analysis of variance (ANOVA) for plant height (PH), grain yield (Y), relative yield loss (RYL), panicle number per $\mathrm{m}^{2}(\mathrm{PN})$, grain number per panicle (GN), 1000-grain weight (THGW), biological yield (BY), harvest index (HI), leaf area index at 25 and 45 days (LAI25 and LAI45) after transplanting, weed biomass (WB), and herbicide efficacy (HE) as affected by herbicide rate, cultivar, and spatial pattern

\begin{tabular}{|c|c|c|c|c|c|c|c|c|c|c|c|c|c|}
\hline $\begin{array}{l}\text { Source of } \\
\text { variation }\end{array}$ & df & $\mathbf{P h}$ & $\mathbf{Y}$ & RYL & PN & GN & THGW & BY & HI & LAI25 & LAI45 & WB & HE \\
\hline Block (R) & 2 & $405^{* *}$ & $2130313^{* *}$ & $177^{\mathrm{ns}}$ & $1242^{\mathrm{ns}}$ & $269^{*}$ & $0.8^{\mathrm{ns}}$ & $4010963^{* *}$ & $3.9^{\mathrm{ns}}$ & $0.00001^{\mathrm{ns}}$ & $0.218^{\mathrm{ns}}$ & $761^{\text {ns }}$ & $146^{*}$ \\
\hline $\begin{array}{l}\text { Herbicide rate } \\
(\mathrm{H})\end{array}$ & 4 & $560^{* * *}$ & $2359702^{* * *}$ & $1565^{* * *}$ & $4404^{* *}$ & $335^{*}$ & $2.3^{\mathrm{ns}}$ & $6298837^{* * *}$ & $0.8^{\mathrm{ns}}$ & $0.00043^{\mathrm{ns}}$ & $2.237^{* * *}$ & $253595^{* * *}$ & $17152^{* * *}$ \\
\hline $\begin{array}{c}\text { Error (a) } \\
\text { Cultivar (C) }\end{array}$ & $\begin{array}{l}8 \\
1\end{array}$ & $\begin{array}{c}19 \\
627^{* * *}\end{array}$ & $\begin{array}{c}50674 \\
1096850^{* *}\end{array}$ & $\begin{array}{c}42 \\
432^{*}\end{array}$ & $\begin{array}{l}411 \\
12^{\text {ns }}\end{array}$ & $\begin{array}{l}52^{\mathrm{ns}} \\
44^{\mathrm{ns}}\end{array}$ & $\begin{array}{c}1.2 \\
2.9^{\mathrm{ns}}\end{array}$ & $\begin{array}{c}378679 \\
4743405^{* *}\end{array}$ & $\begin{array}{c}3.4 \\
2.0^{\mathrm{ns}}\end{array}$ & $\begin{array}{l}0.00036 \\
0.00121^{*}\end{array}$ & $\begin{array}{l}0.035 \\
0.447^{* * *}\end{array}$ & $\begin{array}{l}1470 \\
149^{\text {ns }}\end{array}$ & $\begin{array}{l}85 \\
7^{\text {ns }}\end{array}$ \\
\hline $\begin{array}{l}\text { Spatial Pattern } \\
\text { (S) }\end{array}$ & 1 & $224^{* *}$ & $4348549^{* * * *}$ & $2733^{* * * *}$ & $5080^{* *}$ & $48^{\mathrm{ns}}$ & $0.2^{\mathrm{ns}}$ & $10128832^{* * *}$ & $3.1^{\mathrm{ns}}$ & $0.00181^{* *}$ & $0.358^{* * *}$ & $49415^{* * *}$ & $1311^{* * * *}$ \\
\hline $\mathrm{H}^{*} \mathrm{C}$ & 4 & $23^{\mathrm{ns}}$ & $79076^{\text {ns }}$ & $64^{\mathrm{ns}}$ & $872^{\mathrm{ns}}$ & $25^{\mathrm{ns}}$ & $0.3^{\mathrm{ns}}$ & $242360^{\mathrm{ns}}$ & $2.0^{\mathrm{ns}}$ & $0.00003^{\mathrm{ns}}$ & $0.002^{\mathrm{ns}}$ & $41^{\mathrm{ns}}$ & $4^{\mathrm{ns}}$ \\
\hline $\mathrm{H}^{*} \mathrm{~S}$ & 4 & $39^{\text {ns }}$ & $174780^{\mathrm{ns}}$ & $108^{\text {ns }}$ & $764^{\mathrm{ns}}$ & $76^{\mathrm{ns}}$ & $0.7^{\mathrm{ns}}$ & $471931^{\mathrm{ns}}$ & $0.3^{\mathrm{ns}}$ & $0.00008^{\mathrm{ns}}$ & $0.003^{\text {ns }}$ & $4596^{* * * *}$ & $281^{* * *}$ \\
\hline$C^{*} \mathrm{~S}$ & 1 & $1^{\mathrm{ns}}$ & $188384^{\mathrm{ns}}$ & $150^{\mathrm{ns}}$ & $587^{\mathrm{ns}}$ & $51^{\mathrm{ns}}$ & $0.1^{\mathrm{ns}}$ & $92134^{\mathrm{ns}}$ & $2.9^{\mathrm{ns}}$ & $0.00004^{\mathrm{ns}}$ & $0.008^{\mathrm{ns}}$ & $40^{\mathrm{ns}}$ & $1^{\mathrm{ns}}$ \\
\hline $\mathrm{H}^{*} \mathrm{C} * \mathrm{~S}$ & 4 & $5^{\mathrm{ns}}$ & $15542^{\mathrm{ns}}$ & $13^{\mathrm{ns}}$ & $218^{\mathrm{ns}}$ & $244^{\mathrm{ns}}$ & $0.4^{\text {ns }}$ & $188482^{\mathrm{ns}}$ & $1.5^{\mathrm{ns}}$ & $0.00002^{\mathrm{ns}}$ & $0.001^{\mathrm{ns}}$ & $70^{\mathrm{ns}}$ & $2^{\mathrm{ns}}$ \\
\hline Error (b) & 30 & 29 & 110650 & 70 & 568 & 71 & 0.9 & 601584 & 4.6 & 0.00023 & 0.013 & 739 & 32 \\
\hline
\end{tabular}

$*, * *$, and $* * *$ : significant at the $0.05,0.01$, and 0.001 probability level, respectively.

ns, not significant at the 0.05 probability level. 


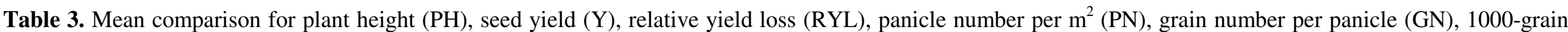
weight (THGW), biological yield (BY), harvest index (HI), leaf area index at 25 and 45 days (LAI25 and LAI45) after transplanting, weed biomass (WB), and herbicide efficacy (HE) response to pretilachlor rate, cultivar, and spatial pattern

\begin{tabular}{|c|c|c|c|c|c|c|c|c|c|c|c|c|}
\hline Factors & $\begin{array}{c}\mathrm{Ph} \\
(\mathrm{Cm})\end{array}$ & $\begin{array}{c}\mathrm{Y} \\
\left(\mathrm{Kg} \mathrm{ha}^{-1}\right)\end{array}$ & $\begin{array}{c}\mathrm{RYL} \\
(\%)\end{array}$ & $\begin{array}{c}\text { PN } \\
\left(\text { No. } \mathrm{m}^{-2}\right)\end{array}$ & $\begin{array}{c}\text { GN } \\
\left(\text { No. } \text { panicle }^{-1}\right)\end{array}$ & $\begin{array}{l}\text { THGW } \\
\text { (g) }\end{array}$ & $\begin{array}{c}\text { BY } \\
\left(\mathrm{Kg} \mathrm{ha}^{-1}\right)\end{array}$ & $\begin{array}{l}\mathrm{HI} \\
(\%)\end{array}$ & LAI25 & LAI45 & $\begin{array}{c}\text { WB } \\
\left(\mathrm{g} \mathrm{m}^{-2}\right)\end{array}$ & $\begin{array}{l}\mathrm{HE} \\
(\%)\end{array}$ \\
\hline \multicolumn{13}{|c|}{$\begin{array}{l}\text { Pretilachlor rates } \\
\left(\mathbf{L ~ h a}^{-1}\right)\end{array}$} \\
\hline 0 & 130 & 2356 & 39.9 & 180 & 77 & 27.0 & 3909 & 37.6 & 0.103 & 0.87 & 371 & - \\
\hline 0.5 & 119 & 2543 & 35.0 & 199 & 84 & 27.3 & 4217 & 37.7 & 0.110 & 1.01 & 352 & 15.6 \\
\hline 1.0 & 122 & 2927 & 24.9 & 208 & 86 & 28.0 & 4853 & 37.6 & 0.100 & 1.27 & 248 & 40.5 \\
\hline 1.5 & 116 & 2954 & 24.4 & 209 & 88 & 27.9 & 5029 & 37.1 & 0.100 & 1.67 & 120 & 71.1 \\
\hline 2.0 & 113 & 3507 & 10.2 & 233 & 91 & 27.7 & 5760 & 37.8 & 0.093 & 1.89 & 36 & 91.2 \\
\hline $\operatorname{LSD}(0.05)$ & 4 & 211 & 6.1 & 19 & 6 & 1.1 & 579 & 1.7 & 0.017 & 0.19 & 36 & 8.6 \\
\hline \multicolumn{13}{|l|}{ Cultivars } \\
\hline 'Hashemi' & 124 & 2722 & 29.6 & 205 & 84.7 & 27.4 & 4472 & 37.8 & 0.106 & 1.26 & 227 & 44.0 \\
\hline 'Deylamani' & 117 & 2993 & 24.2 & 206 & 86.4 & 27.8 & 5035 & 37.4 & 0.097 & 1.43 & 224 & 43.3 \\
\hline LSD (0.05) & 3 & 175 & 4.4 & 12 & 4.4 & 0.5 & 408 & 1.1 & 0.008 & 0.06 & 14 & 3.0 \\
\hline \multicolumn{13}{|l|}{ Spatial patterns } \\
\hline $20 \times 20$ & 122 & 3127 & 20.1 & 215 & 86.4 & 27.5 & 5164 & 37.8 & 0.107 & 1.42 & 197 & 48.3 \\
\hline $30 \times 13$ & 122 & 2588 & 33.6 & 197 & 86.6 & 27.6 & 4343 & 37.3 & 0.096 & 1.26 & 274 & 39.0 \\
\hline LSD (0.05) & 2 & 175 & 4.4 & 12 & 4.4 & 0.5 & 408 & 1.1 & 0.008 & 0.06 & 15 & 3.0 \\
\hline
\end{tabular}


The reduction in plant height of rice due to weed competition was reported by several earlier researchers (BEGUM, 2006; BEGUM et al., 2008). Similarly, Chauhan and Johnson (2010) noted that the reduction in plant height of rice was increased in higher weed density. 'Hashemi' cultivar was significantly taller than 'Deylamani' as averaged across herbicide rates and spatial patterns. Rice plants were significantly taller in uniform pattern $(122 \mathrm{~cm})$ compared to wide-row pattern $(118 \mathrm{~cm})$. This may be contributed greater weed biomass in wide-row pattern (254 $\left.\mathrm{gm}^{-2}\right)$ compared to uniform pattern $\left(197 \mathrm{gm}^{-2}\right)$. Therefore, it seems that stronger competition between weeds and rice for nutrients in wide-row pattern reduced rice plant height.

A quadratic equation expressed the relationship between rice grain yield and herbicide rate (Figure 1). Regardless of cultivar and spatial pattern, grain yield was significantly increased with increasing pretilachlor rate. The highest yields $\left(3507.6 \mathrm{~kg} \mathrm{ha}^{-1}\right)$ were observed in plots receiving 2 $\mathrm{L} \mathrm{ha}^{-1}$ of pretilachlor, while the lowest yields were obtained in plots receiving 0 or $0.5 \mathrm{~L} \mathrm{ha}^{-1}$ of pretilachlor, 2356.5 and $2543.8 \mathrm{~kg} \mathrm{ha}^{-1}$, respectively.
'Deylamani' produced greater grain yield than 'Hashemi' (2993 vs. $2722 \mathrm{~kg} \mathrm{ha}^{-1}$ ) as averaged across pretilachlor rates and spatial patterns. Regardless of pretilachlor rate and cultivar, significantly higher grain yields were recorded in plots with uniform planting patterns $\left(3127 \mathrm{~kg} \mathrm{ha}^{-1}\right)$ compared to the plots with wide-row planting pattern $\left(2588 \mathrm{~kg} \mathrm{ha}^{-1}\right)$. Similar results were reported for wheat by OLSEN et al. (2005), who concluded that there may be other advantages to a uniform planting pattern of the crop in addition to increased weed suppression, such as better absorption of nutrients and utilization of space resources. The interaction between herbicide rate and spatial pattern was not significant for grain yield, indicating that a similar response for grain yield was observed in uniform and row planting pattern to different weed density (due to various application rate of pretilachlor). Contrary to this result, Weiner et al. (2001) reported that the advantage of uniform planting pattern occurs only when weeds are present, while when weeds are absent or well controlled, uniform planting pattern may has no superior to row planting pattern.

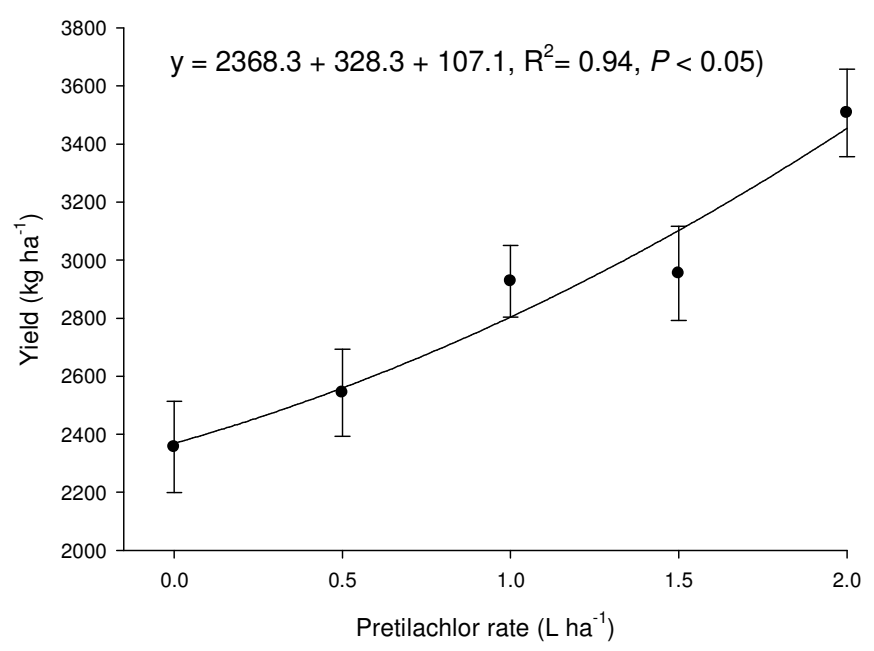

Figure 1. Influence of pretilachlor rate on rice grain yield (averaged across to cultivars and spatial patterns)

Averaged across cultivars and spatial patterns, relative yield loss was significantly reduced from $39.9 \%$ to $10.2 \%$ when pretilachlor rate increased from 0 to $2 \mathrm{~L} \mathrm{ha}^{-1}$ (Table 3). Relative yield loss was significantly greater in 'Hashemi' (29\%) compared to 'Deylamani' (24\%), as averaged across pretilachlor rates and spatial patterns (Table 3). Averaged over cultivars and pretilachlor rates, relative yield loss was significantly greater in widerow planting pattern compared to uniform planting pattern (Table 3). ZHAO et al. (2006) reported that the relative yield losses of rice cultivars caused by weed competition ranged from about 11 to $63 \%$ and concluded that the cultivars had a wide range in both weed-suppressive ability and yield under weed competition.

Averaged across cultivars and spatial patterns, panicle number per $\mathrm{m}^{2}$ and grain number per panicle increased by $29 \%$ and $19 \%$, respectively, as pretilachlor rate increased from 0 to $2 \mathrm{~L} \mathrm{ha}^{-1}$. Regardless of cultivar and pretilachlor rate, rice plants grown in uniform planting pattern produced greater panicle number compared to ones grown in wide-row planting pattern. At the same time, 1000-grain weight was not significantly influenced by pretilachlor rate, cultivar and spatial 
pattern (Table $2 \&$ 3). 'Hashemi' and 'Deylamani' produced similar panicle number per $\mathrm{m}^{2}$ and grain number per panicle, when averaged across pretilachlor rates and spatial patterns (Table $2 \& 3$ ). Spatial pattern also had no significant effect on grain number per panicle (Table $2 \& 3$ ). These results indicated that panicle number per $\mathrm{m}^{2}$ was the most sensitive component to weed competition and spatial pattern. Khaliq et al (2011) reported that all yield components for wheat (productive tiller number $\mathrm{m}^{-2}$, spikelets per spike, grains per spike, and 1000-grain weight) were significantly increased when herbicide application rate increased.

Regardless of rice cultivar and spatial pattern, the highest $\left(5760 \mathrm{~kg} \mathrm{ha}^{-1}\right)$ and the lowest $\left(3909 \mathrm{~kg} \mathrm{ha}^{-1}\right)$ biological yields were obtained when pretilachlor were applied at the rate of 2 and $0 \mathrm{~L} \mathrm{ha}^{-}$ ${ }^{1}$, respectively, while harvest indices were similar among pretilachlor rates (Table 3). This indicates that the percentage reductions of grain yield and of biological yield by different weed pressure (due to various application rates of pretilachlor) were similar. Contrary to this result, Khaliq et al. (2011) concluded that harvest index for wheat was significantly increased with increasing herbicide [Atlantis 3.6WG (iodo+mesosulfuron)] application rate. Averaged across pretilachlor rates and spatial patterns, 'Deylamani' accumulated more biomass than 'Hashemi', but no significant difference in harvest index was found between 'Hashemi' and 'Deylamani' (Table 3). Rice biomass was significantly greater in uniform planting pattern than in wide-row planting pattern when averaged over cultivars and pretilachlor rates, whereas there was no significant difference in harvest index between uniform and wide-row planting patterns (Table 3).

Leaf area index at 25 days after transplanting (LAI25) was not significantly influenced by pretilachlor rates, cultivars and spatial patterns (Table $2 \& 3$ ). Regardless of cultivar and spatial pattern, leaf area index at 45 days after transplanting (LAI45) was significantly increased from 0.89 to 1.43 with increasing herbicide application rate from 0 to $2 \mathrm{~L} \mathrm{ha}^{-1}$ (Table 3), indicating $61 \%$ increases in LAI due to better weed suppression at higher application rate of pretilachlor $\left(2 \mathrm{~L} \mathrm{ha}^{-1}\right)$. Haefele et al. (2004) reported that leaf area index of rice cv. Sahel108 reduced by $32 \%$ due to natural weed competition. 'Deylamani' had more LAI45 than 'Hashemi', when averaged across spatial patterns and pretilachlor rates (Table 3). Contrary to this result, Saito et al. (2010) reported that rice genotypes did not significantly differ in LAI at 42 days after seeding, but significantly differed in LAI at 63 days after seeding under weed-free conditions. Moreover, uniform planting pattern produced significantly greater LAI at 45 days after transplanting than wide-row planting pattern when averaged across cultivars and pretilachlor rates (Table 3).

Averaged across cultivars and spatial patterns, weed biomass reduced and herbicide efficacy increased with increasing pretilachlor rate (Table 3). Significant reduction in weed biomass was achieved when at least $50 \%$ of recommended or higher rates of pretilachlor were applied (Table 3). Barros et al., 2007 and Khaliq et al. (2011) reported similar results and concluded that significant weed suppression can be achieved with reduced herbicide rates. Uniform planting pattern of rice plants suppressed weeds $39 \%$ and improved herbicide efficacy $23 \%$ better than wide-row planting pattern as averaged across pretilchlor rates and cultivars (Table 3). Regardless of cultivar, uniform planting pattern of rice plants suppressed weeds $22 \%, 24 \%$, $15 \%$, and $32 \%$ better than wide-row planting pattern when pretilachlor was applied at the rate of $0.0,0.5$, 1.0, $1.5 \mathrm{~L} \mathrm{ha}^{-1}$, respectively, but there was no significant difference in weed biomass between uniform and wide-row planting patterns when pretilachlor was applied at the rate of $2 \mathrm{~L} \mathrm{ha}^{-1}$ (Figure 2). Averaged across to cultivars, uniform planting pattern improved herbicide efficacy by $57 \%, 28 \%, 17 \%$ compared to wide-row planting pattern when pretilachlor was applied at the rate of $0.5,1.0,1.5 \mathrm{~L} \mathrm{ha}^{-1}$, respectively, while no significant difference was observed for herbicide efficacy between uniform and wide-row planting patterns when pretilachlor was applied at the rate of $2 \mathrm{~L} \mathrm{ha}^{-}$ ${ }^{1}$ (Figure 3). It has been suggested that an equidistant spacing of crop plants hasten canopy closure and increase crop competitiveness which may reduce light penetration or affect light quality (or both) under the crop canopy. This may restrict germination, growth of weed seedlings, and seed production of late-season weeds (BAGAVATHIANNAN et al., 2011). Weed biomass and herbicide efficacy in 'Hashemi' was equal to those observed in 'Deylamani' when averaged across pretilachlor rates and spatial patterns (Table 3). Contrary to this result, Gealy et al. (2003) reported that 'PI 3127779' rice cultivar suppressed barnyardgrass more than did 'Lemont'. Moreover, Saito et al. (2010) found large variation in weed biomass among rice genotype. 


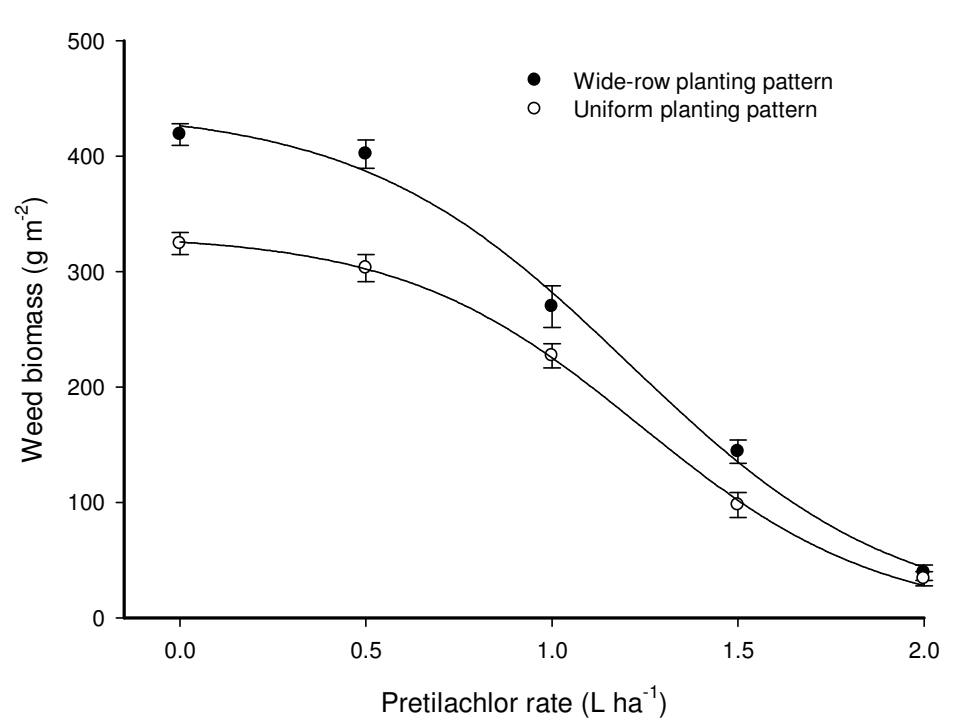

Figure 2. Influence of pretilachlor rate on weed biomass in uniform $(\circ)$ and wide-row $(\bullet)$ planting patterns (averaged across to cultivars). Vertical bars represent $\pm 1 \mathrm{SE}$ of means. Fitted lines are based on the equations: $\mathrm{y}=332.2 /(1+\exp (-(\mathrm{x}-1.2) /-0.3))), \mathrm{R}^{2}=0.99, P<0.01$ (uniform planting pattern); and $\mathrm{y}=$ $441.2 /(1+\exp (-(\mathrm{x}-1.2) /-0.3))), \mathrm{R}^{2}=0.99, P<0.01$ (wide-row planting pattern)

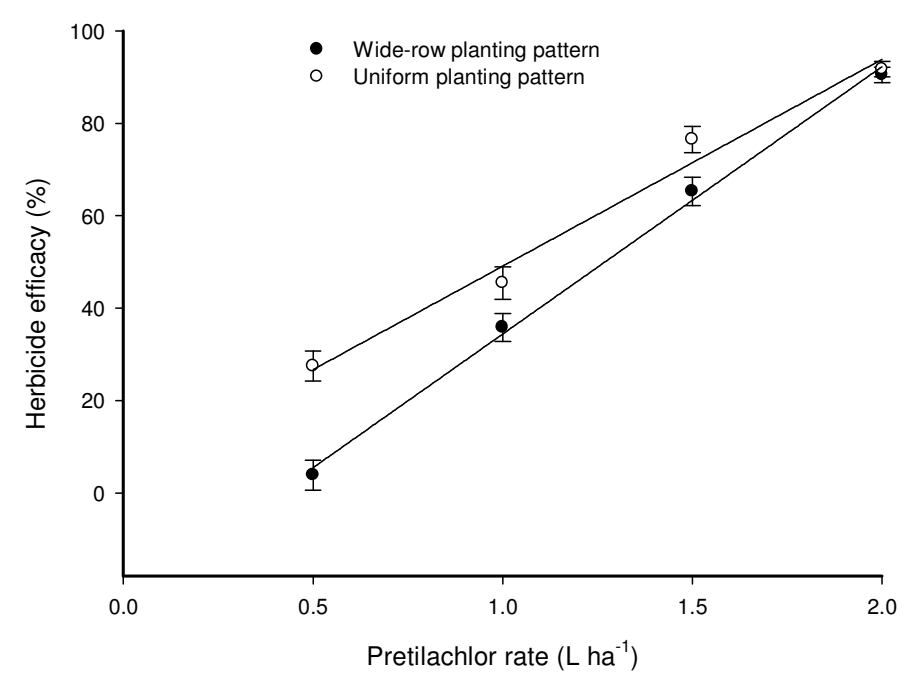

Figure 3. Influence of pretilachlor rate on herbicide efficacy in uniform $(\circ)$ and wide-row $(\bullet)$ planting patterns (averaged across to cultivars). Vertical bars represent \pm 1 SE of means. Fitted lines are based on the equations: $\mathrm{y}=4.3+44.7 \mathrm{x}, \mathrm{R}^{2}=0.97, P<0.01$ (uniform planting pattern); and $\mathrm{y}=-23.4+57.8 \mathrm{x}$, $\mathrm{R}^{2}=0.99, P<0.01$ (wide-row planting pattern)

\section{CONCLUSION}

This experiment illustrated that uniform planting pattern suppressed weeds $39 \%$ better than wide-row planting pattern, and can play an important role in increasing the crop's competitive advantage over weeds. There were no significant differences in weed biomass between 'Hashemi' and 'Deylamani'. At the same time, rice grain yield and herbicide efficacy increased, while weed biomass decreased as pretilachlor application rate increased.

RESUMO: Para avaliar os efeitos da taxa de herbicida, cultivar e padrão espacial em arroz produção de grãos e supressão de plantas daninhas, um experimento de campo foi realizado em um campo de arroz irrigado na Estação de Pesquisa do Arroz de Tonekābon, norte do Irã, em 2011. O delineamento experimental foi uma fração de lote - fatorial , onde toda a parte de enredo foi em blocos casualizados com três repetições. As parcelas foram as taxas pretilaclor $(0,0.5$, 
1, 1.5 , $2 \mathrm{~L} \mathrm{ha}^{-1}$ de pretilaclor). As subparcelas foram combinações fatoriais de dois padrões de culturas espaciais ( uniformes e padrões de plantio em toda a linha, $20 \times 20$ e $30 \times 13 \mathrm{~cm}$, respectivamente) e duas cultivares de arroz tradicionais (' Hashemi ' e ' Deylamani '). Independentemente de cultivar e padrão espacial , grãos de arroz e os rendimentos biológicos, número de panículas por $\mathrm{m}^{2}$, o índice de área foliar e eficácia do herbicida aumentou, enquanto a biomassa de plantas daninhas diminuiu com o aumento da taxa de aplicação pretilaclor . O grão de arroz e os rendimentos biológicos , número de panículas por $\mathrm{m}^{2}$, o índice de área foliar e eficácia do herbicida foram significativamente maiores no padrão de plantio uniforme do que em toda a linha de plantio padrão quando calculados sobre cultivares e taxas pretilaclor . Além disso, o plantio uniforme padrão de plantas de arroz suprimida ervas daninhas 39\% melhor do que em toda a linha de plantio padrão como média entre as taxas de pretilchlor e cultivares . ' Deylamani "produzido grão ralador e os rendimentos biológicos, número de panículas por $\mathrm{m}^{2}$, índice de área foliar do que" Hashemi ", como média entre as taxas de pretilaclor e padrões espaciais. Este experimento mostrou que padrão espacial uniforme aumento supressão de plantas daninhas, eficácia do herbicida, e rendimento de grãos.

PALAVRAS CHAVE: Herbicida. Plantio padrão. Cultivares de arroz. A competição de plantas daninhas

\section{REFERENCES}

BAGAVATHIANNAN, M. V.; NORSWORTHY, J. K.; SMITH, K. L. 2011. Growth and reproduction of barnyardgrass (Echinochloa crus-galli) under different soybean densities and distances from soybean rows. Proc. South. Weed Science Soc. v. 64, 298.

BARROS, J. F. C.; BASCH G., CARVALHO, M. Effect of reduced doses of a post-emergence herbicide to control grass and broadleaved weeds in no-till wheat under Mediterranean conditions. Crop Protection, v. 26, p. 1538-1545. 2007. http://dx.doi.org/10.1016/j.cropro.2006.12.017

BEGUM, M.; JURAIMI, A. S.; RAJAN, A.; SYED OMAR S. R.; AZMI M. Critical period competition between Fimbristylis miliacea (L.) Vahl and Rice (MR 220). Plant Protection, v. 23, p. 153-157, 2008.

BEGUM, M. Biology and Management of Fimbristylis miliacea (L.) vahl. PhD Thesis. Universiti Putra Malaysia, 2006.

CHAUHAN, B. S.; JOHNSON, D. E. Relative importance of shoot and root competition in dry-seeded rice growing with jungle rice (Echinochloa colona) and ludwigia (Ludwigia hyssopifolia). Weed Science, v. 58, p. 295-299, 2010. http://dx.doi.org/10.1614/WS-D-09-00068.1

GEALY, R. D.; WAILES, E. J.; LEOPOLDO, E.; ESTORNINOS, J. R.; CHAVEZ, R. S. C.. Rice cultivar differences in suppression of barnyardgrass (Echinochloa crus-galli) and economics of reduced propanil rates. Weed Science, v. 51, p. 601-609, 2003. http://dx.doi.org/10.1614/0043-

1745(2003)051[0601:RCDISO]2.0.CO;2

GIBSON, K. D.; FISCHER, A. J.; FOIN, T. C.; HILL, J. E. Crop traits related to weed suppression in water seeded rice (Oryza sativa). Weed Science, v. 51, p. 87-93, 2003. http://dx.doi.org/10.1614/00431745(2003)051[0087:CTRTWS]2.0.CO;2

GOMEZ, K. A. Techniques for field experiment with rice. International Rice Research Institute, Los Banos, 48P, 1972.

HEAFELE, S. M.; JOHNSON, D. E.; M'BODJ, D.; WOPEREIS, M. C. S.; MIEZAN, K. M. Field screening of diverse rice genotypes for weed competitiveness in irrigated lowland ecosystems. Field Crops Research, v. 88, p. 39-56, 2004. http://dx.doi.org/10.1016/j.fcr.2003.11.010

HEAP, I. The International Survey of Herbicide-Resistant Weeds. http:// www.weedscience.org. Accessed: January, 25, 2010. 
JANNINK, J. L.; ORF, J. H.; JORDAN, N. R.; SHAW, R. G. Index selection for weed suppressive ability in soybean. Crop Science, v. 40, p. 1087-1094, 2000. http://dx.doi.org/10.2135/cropsci2000.4041087x

KHALIQ, A.; MATLOOB, A.; TANVEER, A.; AREEB, A.; ASLAM, F.; ABBAS, N. Reduced doses of a sulfonylurea herbicide for weed management in wheat fields of Punjub, Pakistan. Chilean Journal of Agricultural Research, v. 71, n. 3, p. 424-429, 2011. http://dx.doi.org/10.4067/S0718-58392011000300013

LESNIK, M. The impact of maize stands density on herbicide efficiency. Plant, Soil, and Environment, v. 49, n. 1, p. 29-35, 2003.

MASON, H.; GOONEWARDENE, L.; SPANER, D. Competitive traits and the stability of wheat cultivars in differing natural weed environments on the northern Canadian Prairies. Journal of Agricultural Science, v. 146, p. 21-33, 2008. http://dx.doi.org/10.1017/S0021859607007319

OLSEN, J. M., GRIEPENTROG, H. W.; NIELSEN, J.; WEINER J. How important are crop spatial pattern and density for weed suppression by spring wheat? Weed Science, v. 60, p. 501-509, 2012.

http://dx.doi.org/10.1614/WS-D-11-00172.1

OLSEN, J. M.; KRISTENSEN, L.; WEINER, J.; GRIEPENTROG, H. W. Increased density and spatial uniformity increases weed suppression by spring wheat (Triticum aestivum). Weed Research, v. 45, p. 316321, 2005. http://dx.doi.org/10.1111/j.1365-3180.2005.00456.x

PAYNTER, B. H.; HILLS, A. L. Barley and rigid ryegrass (Lolium rigidum) competition is influenced by crop cultivar and density. Weed Technology, v. 23, p. 40-48, 2009. http://dx.doi.org/10.1614/WT-08-093.1

POWLES, S. B.; YU, Q. Evolution in action: plants resistant to herbicides. Annual Review of Plant Biology, v. 61, p. 317-347, 2010. http://dx.doi.org/10.1146/annurev-arplant-042809-112119

SAITO, K.; AZOMA, K.; RODENBURG, J. Plant characteristics associated with weed competitiveness of rice under upland and lowland conditions in West Africa. Field Crops Research, v. 116, p. 308-317, 2010.

http://dx.doi.org/10.1016/j.fcr.2010.01.008

SAS, SAS Institute, version 9.1.3. Cary, NC, USA, 2004.

SHIVRAIN, V. K.; BURGOS, N. R.; GEALY, D. R.; SMITH, K. L.; SCOTT, R. C.; MAUROMOUSTAKOS, A.; BLACK, H. Red rice (Oryza sativa) emergence characteristics and influence on rice yield at different planting dates. Weed Science, v. 57, p. 94-102, 2009. http://dx.doi.org/10.1614/WS-08-112.1

SINGH, I.; RAM, M.; NANDAL, D. P.. Efficacy of new herbicides for weed control in transplanted rice under rice-wheat system. Indian J. Weed Science, v. 38, p. 28-31, 2007.

SPIES, M.; WARKENTIN, T. D.; SHIRTLIFFE, S. J.. Variation in Field Pea (Pisum sativum) Cultivars for Basal Branching and Weed Competition. Weed Science, v. 59, p. 218-223, 2011.

http://dx.doi.org/10.1614/WS-D-10-00079.1

WEINER, J.; GRIEPENTROG, H. W.; KRISTENSEN, L.. Suppression of weeds by spring wheat (Triticum aestivum) increases with crop density and spatial uniformity. Journal of applied Ecology, v. 38, p. 784-790, 2001. http://dx.doi.org/10.1046/j.1365-2664.2001.00634.x

ZHAO, D. L.; ATLIN, G. N.; BASTIAANS, L.; SPIERTZ, J. H. J. Cultivars weed competitiveness in aerobic rice: Heritability, correlated traits, and the potential for indirect selection. Crop Science, v. 46, p. 372-380, 2006. http://dx.doi.org/10.2135/cropsci2005.0192 